\title{
What causes the failure of inflation stabilization plans?
}

\author{
Francisco José Veiga* \\ Universidade do Minho \\ Escola de Economia e Gestão \\ 4700 Braga - Portugal
}

\begin{abstract}
:
The paper discusses the causes of failure of inflation stabilization plans. Following a description of stylized facts of inflation stabilization, a model of Balance of Payments crises is presented, highlighting some of the main factors leading to the collapse of stabilizations. Empirical results obtained when estimating a binary probit model over a panel of 34 stabilizations identify real exchange rate appreciation, lack of foreign reserves, and government budget deficits as the main causes of failure of inflation stabilization plans. This is consistent with the model presented in this paper, with the stylized facts of stabilizations, and with some of the models found in the literature.
\end{abstract}

Key words: Inflation; Stabilization; Chronic inflation countries

JEL classification: E31; E63; F41

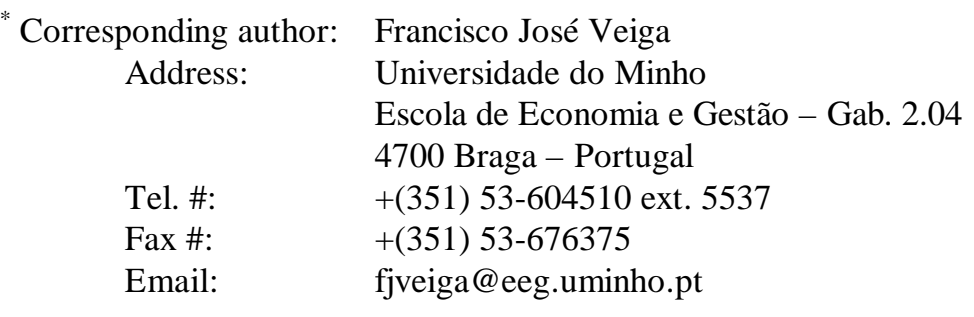




\section{INTRODUCTION}

Unlike the hyperinflations of the 1920s that were stopped quickly and with minor output costs through the use of the exchange rate as the nominal anchor, chronic inflation in many developing countries has proved much more difficult to eliminate. Since the 1950s, several countries have tried to eliminate chronic inflation by implementing stabilization programs in which the exchange rate or the money supply is used as the nominal anchor. Regardless of the anchor used, it has taken much longer to eliminate high inflation than it took to eliminate the hyperinflations of the 1920s.

A wide literature exists on the stylized facts of stabilizations and on models that try to explain those facts, but not much has been done in terms of estimating the main causes of the failure of stabilization attempts. This is what I try to accomplish. I estimate a binary probit model over a panel of 34 stabilization programs in order to identify the macroeconomic variables that have had a greater effect on the probability of failure of a stabilization. Empirical results identify real exchange rate appreciation, budget deficits, and lack of international reserves as the main causes of failure. This is consistent with the model presented in this paper, with the stylized facts of stabilizations, and with many of the models found in the literature.

The structure of the paper is as follows. Section 2 reviews the stylized facts of inflation stabilization. Section 3 analyses models that deal with the credibility of a plan and develops a model of Balance of Payments (B.O.P.) crises highlighting some of the main factors leading to the 
failure of stabilizations. The empirical analysis is presented in Section 4, political factors behind public deficits are discussed in Section 5, and conclusions are presented in Section 6.

\section{STYLIZED FACTS OF INFLATION STABILIZATION ${ }^{1}$}

Although stabilization plans are not all alike, it is possible to identify some empirical regularities associated with fighting inflation in chronic inflation countries. Chronic inflation is usually understood as high inflation relative to the levels typical of industrial countries, and tends to persist for a long period of time - its duration is not measured in months, like in hyperinflation, but in years (Pazos, 1972). Since the effects on the economy of choosing the exchange rate or the money supply as the nominal anchor are generally not the same, the empirical regularities of the two types of plans are identified separately. A list of the stabilization plans analyzed in this paper is presented in Table 1.

\subsection{Exchange Rate-Based Stabilization (ERBS)}

Although hyperinflations were usually stopped very quickly and with minor output costs when the exchange rate was used as the nominal anchor (see Sargent, 1982), the same has not happened when dealing with chronic inflation. It usually takes longer, or the stabilization fails completely

\footnotetext{
${ }^{1}$ The identification of the stylized facts of stabilizations and of the plans presented in Table 1 was based on: Calvo and Végh (1994); Kiguel and Leviatan (1991, 1992a); and Végh (1992). Also related to stylized facts of Exchange Rate-Based programs, are: Dornbush, et al. (1995); and Rebelo and Végh (1995). For studies on specific plans of several countries, see: Bruno, et al. (1988); Bruno, et al. (1991); and Pazos (1972).
} 
with inflation coming back "with a vengeance". In this case, the effects on output are generally considerable. The empirical regularities usually emphasized in the literature are:

- slow convergence of inflation to the rate of depreciation: while the rate of depreciation of the currency is generally greatly reduced, inflation is not reduced with the same speed;

- real appreciation of the domestic currency: the price of domestic goods increases relative to foreign goods, with a consequent loss of competitiveness;

- deterioration of the trade balance and current account: they are usually fueled by large imports of durable and capital goods (sometimes made easier by a trade liberalization);

- initial increases in output and consumption followed by a slowdown ${ }^{2}$ : with lower inflation and cheaper imported goods, purchasing power increases and there is a boom in consumption, mainly of durable goods. Other possible causes: initial fall in real interest rates; the reduction in the inflation rate may be seen as only temporary; positive effects of a reduction in the budget deficit and of the inflation tax;

${ }^{2}$ On the business cycle effects of ERBS and MBS, see: Kiguel and Leviatan (1992b). Rebelo and Végh (1995) present an analysis of the competing theories about the effects of ERBS and try to assess, qualitatively and quantitatively, the different hypothesis using an unified framework (they run simulations of a Real Business Cycle model for the different hypothesis and evaluate how well they replicate the stylized facts of ERBS). 
- ambiguous response of domestic real interest rates: the behavior seems to depend on the plan being orthodox or heterodox (price and wage controls used in the latter) - decline in the former and increase in the latter;

- an increase in real wages, especially during the boom;

- failure to reduce the fiscal deficit seems to dampen the reduction of the inflation rate and make real appreciation worse. Programs where a fiscal adjustment is partial or absent usually get quickly off track, and there is a return to the inflation tax;

- the use of price and wage controls as an additional anchor does not seem to change the final result, and the advantages of better fighting inflation inertia are sometimes more than offset by the distortions of relative prices and the problems related to the later removal of controls; ${ }^{3}$

- using money as an additional anchor would generally make the subsequent real appreciation, and high interest rates even worse, reducing the initial boom.

\footnotetext{
${ }^{3}$ Kiguel and Leviatan $(1991,1992 b)$ argue that the greater inflation instability in Brazil and Argentina after the Cruzado and Austral plans was a consequence of the large reliance on incomes policies to fight inflation in the absence of the necessary fiscal adjustment. They suggest a move towards orthodox plans in order to restore the credibility of conventional anchors and avoid the problems related to the misuse of price and wage controls.
} 


\section{2. $\quad$ Money-Based Stabilization (MBS)}

Given the smaller incidence of this kind of plan among countries suffering from chronic inflation, it is not as easy to make generalizations as for the exchange rate-based plans. Nevertheless, some stylized facts are mentioned in the literature:

- slow convergence of inflation to the rate of monetary growth, although it is generally faster than in exchange rate-based plans;

- real appreciation of the domestic currency: usually due to the initial rise in interest rates, sticky inflation, and an imperfect float of the exchange rate (some countries adopted a crawling peg instead of a free float of the domestic currency);

- ambiguous behavior of the trade balance and current account, although there may be some evidence of a short-run improvement;

- initial contraction of economic activity followed by a later expansion: it seems that the business cycle effects of MBS are the opposite of ERBS; ${ }^{4}$

\footnotetext{
${ }^{4}$ Kiguel and Leviatan (1992a), Calvo and Végh (1994), and Végh (1992) argue that the choice of the nominal anchor might dictate the timing of the recession. On ERBS the recession would come in the end, and on MBS it would come in the beginning. Hoffmaister and Végh (1996) test this hypothesis using a vector-autoregression model for Uruguay, and they find that the impulse response of output to different stabilization policies is broadly consistent with the "recession-now-versus-recession-later" hypothesis.
} 
- initial increase in domestic real interest rates, due to the decrease in liquidity usually associated with money-based stabilizations.

\section{A Model of Plan Failure}

According to several models found in the literature, the credibility of a stabilization program can determine or largely influence a program's success or failure. Calvo $(1986,1991)$, argues that if private agents believe that the reduction in inflation is only temporary, there will be a consumption boom, making the inflation rate harder to reduce and worsening the external accounts and, in the end, the stabilization may be welfare reducing ${ }^{5}$. Dornbusch (1991), draws attention to the factors that raise or lower the ex ante probability of success of a plan, explaining why the credibility of a program may be less than perfect. He models an exchange rate based stabilization as a one-shot game in which the policymaker faces a tradeoff between costly adjustment effort (expenditure or wage cuts, or real exchange rate depreciation) and the probability of success of the program. Orphanides (1996), expands Dornbusch's model to also examine the delay in the adoption of a ERBS program and its abandonment as optimal decisions of a policymaker. He argues that it may be better to delay the program if more favorable initial conditions are expected. Agénor (1994), discusses the use of the exchange rate as a nominal anchor for the price level, and the "credibility

${ }^{5}$ Calvo (1986) argues that if the reduction in inflation is seen as temporary, the boom in consumption will be higher, since the accompanying temporary reduction in interest rates makes effective consumption today cheaper than tomorrow. He also argues than the shorter the horizon of the temporary policy, the higher will be its real effects (this is usually known as the "temporariness hypothesis"). Temporary policies would not work on moneybased plans either: a temporary reduction in the rate of money growth would be worse than keeping it constant (Calvo, 1991). The conclusion is that temporary or partial stabilization ends up being welfare reducing. 
effect' that a fixed exchange rate may attach to a disinflation program when policymakers are clearly committed to defend the established parity.

In the models referred above lack of credibility arises from insufficient adjustment efforts, timeinconsistency problems, or asymmetric information. Equally important, or even more important, for explaining the failure of stabilization programs is the case in which programs are not credible because they are inconsistent with other policies being implemented, and they are recognized as such by the public. Krugman (1979) illustrated a common case among exchange rate based stabilizations, in which a fixed exchange rate becomes impossible to sustain due to inconsistencies with fiscal or monetary policies, leading to what he calls a "Balance-of-Payments crisis".

Krugman's model is expanded in this section to incorporate the production of non-tradable goods in a way that allows the study of the behavior of the real exchange rate. The dynamics leading to the collapse of a fixed exchange rate is in accordance with the stylized facts of stabilizations described in section II: real exchange rate appreciation (increase in the relative price of non-traded goods); continuous depletion of foreign reserves; increase in imports; budget deficits make the depletion of reserves faster, etc..

\subsection{Basic framework}

One assumes a small open economy producing two types of goods: tradables, $T$, and nontradables, $N$. The foreign price of the tradable good, $P_{T}{ }^{*}$, is set in world markets and Purchasing Power Parity (PPP) prevails for tradable goods, $P_{T}=E . P_{T}{ }^{*}$, where $P_{T}$ is the domestic price of the 
tradable good, and $E$ is the price of foreign currency in units of the domestic currency. For simplicity, $P_{T}{ }^{*}$ is assumed to be fixed and equal to one. The relative price of non-tradables (our definition of the real exchange rate) is then:

$q=\frac{P_{N}}{E \cdot P_{T}^{*}}=\frac{P_{N}}{E}\left(P_{T}^{*}=1\right)$

As in Krugman's model, domestic agents can hold only two assets: domestic money, $M$; and foreign money, $F$. These assets bear zero nominal interest and foreign agents do not hold domestic money. Wealth of domestic agents in foreign units is the sum of the foreign currency value of their holdings of domestic and foreign money:

$W=\frac{M}{E}+F$

With $M$ being the outstanding stock of domestic money, and assuming that desired holdings are proportional to wealth, the portfolio balance equilibrium is:

$\frac{M}{P_{T}}=\frac{M}{E}=m=L(\pi) W$

I assume, as is normal, that the factor of proportionality $L$ depends inversely on domestic inflation, $\pi$. Combining (2) and (3), we get: 
$m=h(\pi) F \quad$ where $\quad h(\pi)=\frac{L(\pi)}{1-L(\pi)} \quad$ and $\quad h^{\prime}(\pi)<0$

\subsection{Non-traded goods market equilibrium}

The excess demand for $N$ goods, $E_{D}$, is given by the difference between desired consumption, $C_{N}$, and production, $X_{N}$. The standard assumption concerning production and consumption is adopted. The former depends positively on the relative price of non-tradables, $q$, while the latter depends inversely on $q$, but positively on disposable income, $Y$ - $T$, and real wealth, $W$. Assuming disposable income $(Y-T)$ as given, we get:

$E_{D}=C_{N}(\stackrel{+}{q}, \stackrel{+}{W})-X_{N}(\stackrel{+}{q})=E_{D}(\stackrel{-}{q}, \stackrel{+}{W})$

Assuming that the $N$-good market clears always through adjustments in $P_{N}$, we get:

$q=Q \stackrel{+}{W}) \quad, \quad Q_{1}>0$

Although $W$ is given at a specific point in time, it changes via the balance of trade, and money growth, via the government deficit. The market for the nontraded good is shown on Figure 1. There, an increase in $W$ causes an upward movement of the $C_{N}$ schedule along the $X_{N}$ schedule, increasing $X_{N}, C_{N}$ and $q$.

\section{-- Insert Figure 1 about here --}




\subsection{Dynamics}

\section{Flexible exchange rate}

It is assumed that money is created through the government deficit and that the deficit is financed entirely by printing money $\left(\dot{M} / P_{T}=G-T\right)$. Also assume that the deficit is kept as a constant fraction of the money supply. Thus, $G$ adjusts to $m$ in order to make $G-T=g m$, where $g$ is constant. This means that $\dot{M} / M=(G-T) / m$. Also, the growth in real money of the home country depends only on the rate of inflation (or rate of currency depreciation):

$$
\frac{\dot{m}}{m}=\frac{\dot{M}}{M}-\frac{\dot{P}}{P} \Rightarrow \dot{m}=(g-\pi) \cdot m \quad \text { where } \quad \pi \equiv \frac{\dot{P_{T}}}{P_{T}}=\delta \equiv \frac{\dot{E}}{E}
$$

Growth in foreign money holdings equals the current account balance:

$$
\dot{F}=B=Y-G-C(Y-T, W)
$$

In this expression, $C(Y-T, W)$ refers to the traded-goods value of total consumption. The system can be expressed completely in terms of $m$ and $F$, since according to (4) we know that if $m=h(\pi) F \Rightarrow \pi=h^{-1}(m / F)=\pi(m / F)$. With $T=0$ and $G=g m$, we have: 


$$
\left\{\begin{array}{l}
\dot{m}=\left(g-\pi\left(\frac{m}{F}\right)\right) m \\
\dot{F}=Y-g m-C(Y, m+F)
\end{array}\right.
$$

\section{-- Insert Figure 2 about here --}

This system is illustrated in Figure 2, with the arrows indicating the way in which the variables move. There is only one path converging to a steady state: starting at any point along $S S$, like point $A$, the system converges to point $B$ (the steady state); but if we start outside this stable path, the system will diverge even further from the steady state. If the initial holdings of foreign money are $F_{0}$, the price level will adjust to make real domestic supply equal to $m_{0}$, so that the economy stays on $S S$, represented by the following equation:

$P=M \cdot G(F), \quad G_{1}<0$

\section{Fixed exchange rate}

Now assume that the government has a stock $R$ of foreign money that is used to fix the exchange rate. Private savings, assuming $T=0$, are:

$S=Y-C(Y, W)$

Assuming $\dot{M} / P_{T}=G-T$ and combining it with (8), we get: 
$\dot{W}=\frac{\dot{M}}{P}+\dot{F}=S \quad$ and $\quad S=0($ or $\dot{W}=0)$ for $W=\hat{W}$

When $S>0$, wealth grows and is allocated as follows between the two forms:

$$
\begin{aligned}
& \frac{\dot{M}}{P}=L S \quad L \equiv L(0), \pi=0 \\
& \dot{F}=(1-L) S
\end{aligned}
$$

In a fixed exchange rate regime, the government can pay for its deficit either by printing more domestic money or by spending reserves. The problem is that it is unable to determine the way in which the deficit is financed, since if it issues more domestic money than private agents want, they can always trade it for foreign money, decreasing government reserves. In other words, reserves change according to:

$$
\dot{R}=L S-(G-T)=L S-g m
$$

With $S>0$, people save by not spending, which creates a trade surplus. Part of the new wealth is traded to the Central Bank for home money. But, the government is also creating money ( $g m$ ). Reserves adjust to whichever is larger. Since $m=L W$, we know that:

$$
\dot{R}=0 \quad \text { when } \quad L(S-g W)=0 \quad \Rightarrow \quad W=\tilde{W}<\hat{W}
$$


Figure 3 illustrates the dynamic behavior under fixed exchange rates, with the arrows indicating the direction in which the variables move. In the presence of a deficit $(g m>0)$ reserves will fall, once total wealth passes $\tilde{W}$. If the deficit were zero, the two vertical lines in the picture would coincide and it could be possible to reach an equilibrium if initial reserves were large enough. Finally, note that because of (6) the path of the relative price $q$ follows the path of real wealth, $W$.

\section{-- Insert Figure 3 about here --}

The importance of solid public finance on ERBS is illustrated here: the greater the deficit, the quicker is the drainage of reserves and the more difficult is the exchange rate peg to maintain. Furthermore, the real exchange rate will appreciate, worsening external accounts.

\subsection{Collapse}

The gradual decline of reserves referred to above will turn into a "Balance of Payments crisis" when it becomes evident that the peg will eventually be abandoned, and private agents trade as much domestic for foreign money as they can. Agents would suffer a windfall capital loss if there were a discrete jump in the price level when reserves were exhausted and the peg abandoned (with a move towards flexible exchange rates). Thus, when they anticipate a collapse, they exchange domestic for foreign money, avoiding any losses and possibly making big profits when the domestic currency depreciates. With all investors acting this way (assuming perfect foresight) reserves will be exhausted by a speculative attack that occurs early enough to eliminate any 
unusual profit. Later, we examine the case in which agents do not know exactly how large the government's reserves are.

At any time under a fixed rate regime private agents can move along the "constant wealth locus" $W W$, up to a distance corresponding to the stock of international reserves, as shown in Figure 4. The ray labeled $O X$ represents the typical investor's preferred portfolio when the exchange rate is fixed $(\pi=0)$ and credibly so. As domestic money is steadily created, the economy moves continuously out the $O X$ ray: both real wealth and the relative price of the non-tradable, $q$, slowly rise. The collapse occurs when $R$ is just sufficient to allow agents to reach the stable path of the flexible rate case, $S S$, with no change in the exchange rate or price level.

\section{-- Insert Figure 4 about here --}

The path is: $\quad A \rightarrow B \rightarrow C \rightarrow D$

$A \rightarrow B: \downarrow R, \uparrow W, \uparrow q$

$B \rightarrow C$ : Stock shift: reserves taken, $q$ constant

$C \rightarrow D: \uparrow E, \uparrow P_{T}, \downarrow W \Rightarrow q \downarrow \quad$ (stable path towards the steady state $D$ ).

The behavior of the variables from $A$ to $B$ corresponds to some of the stylized facts of ERBS referred in section II: reserves gradually decline; the relative price of nontraded goods rises and, consequently, so does the real exchange rate; and there is an increase in wealth leading to a rise in consumption (and imports). Notice that the real appreciation reflects an over-issue of money 
through the deficit. It is the latter which causes the trade deficit, fundamentally, and the rise in $q$ is necessary to clear the market. ${ }^{6}$

Figure 5 illustrates the case in which the central bank decides to devalue before the total depletion of reserves. As in Figure 4, total reserves are $B R$ and a speculative attack would occur at point $B$ if the entire stock of reserves was used to defend the parity. But if the central bank refuses to support the currency after losing $B R$ ' there will be a discrete jump in the exchange rate so that the economy may move from point $E$ (on $W W$, the constant wealth locus) to $F$ (on $S S$, the floating rate stable path), and investors will suffer a windfall capital loss illustrated by the move from $W W$ to $W^{\prime} W^{\prime}$. Importantly, $q$ would fall discretely, since the devaluation results in a fall in real wealth.

\section{-- Insert Figure 5 about here --}

But, as described earlier, under perfect foresight agents could have avoided these losses by attacking the currency earlier. Thus, when a devaluation is expected before the total depletion of reserves, the speculative attack will occur earlier. Under a more realistic assumption of less than perfect foresight, investors are not sure when the devaluation occurs and, although they attack the currency earlier, there may be a discrete jump in the exchange rate as illustrated in Figure 5. That is what we observed in most of the ERBS episodes studied.

\section{EMPIRICAL EVIDENCE}

\footnotetext{
${ }^{6}$ Flood and Garber (1984) developed a linear version of Krugman's (1979) model that allows them to derive the precise time of collapse. Connolly and Taylor (1984) extended the model for a crawling-peg and incorporate nontraded goods in the model so that the evolution of the real exchange rate could be analyzed. Obstfeld (1984) analyses the case in which a central bank stops defending its currency letting it float for some time and repegs it at a more depreciated level later on. For further developments of the B.O.P. crises literature see Agénor and Flood (1994).
} 
Several models that can be used to explain the failure of stabilization plans were discussed in the previous section. Small adjustment effort, the decision of a policymaker to abort a program, lack of credibility, or a balance-of-payments crisis, can all lead to the failure of a stabilization regardless of its kind (exchange rate based, or money based). This wide range of explanations, together with others not described in this paper, leads to a wide set of models that one could try to test empirically. In order to be able to test the model of the previous section and say something about some of the models found in the literature at the same time, I decided to adopt a reducedform model that allows me to investigate which macroeconomic variables have more effect on the probability of failure of a plan.

\subsection{The Data}

Most of the variables were taken from the December of $1996 \mathrm{CD}-\mathrm{ROM}$ edition of the International Financial Statistics (IFS) produced by the International Monetary Fund (IMF). For each country, I collected quarterly data from the quarter in which the plan was implemented until the quarter in which it failed, or until the fourth quarter of 1995, if the plan had not failed by then. Table 1 reports the initial quarter and length for each of the plans I was able to identify. ${ }^{7}$ The following variables were obtained from the IFS: end-of-period and period-average exchange rates; total reserves minus gold; domestic credit; domestic credit - claims on private sector; money;

\footnotetext{
${ }^{7}$ One should note that Table 1 does not present the complete list of stabilization plans implemented in the world. The criterion was to include the plans that are more commonly referred to in the literature. Some plans were not included because they did not last for more than one quarter, which makes the analysis of the evolution of the variables during the plan impossible with quarterly data. Others were not included because of scarcity of data.
} 
interest rates; consumer price index; exports in USD; imports in USD; current account in USD; government deficit or surplus; GDP; and GDP at 1990 prices. $^{8}$ Quarterly data is not always available for some of the countries studied but, with some exceptions, annual data usually are. In order to make possible the inclusion of the observations for which only annual data was available in the data set, straight-line interpolation was used to generate quarterly data. ${ }^{9}$

\section{-- Insert Table 1 about here --}

Table 2 shows the pattern of failure and censoring for the 34 stabilization plans considered in this paper. The second column shows the number of plans at risk of failure, that is, that were still active at the beginning of the designated quarter. The third column shows how many plans failed at each quarter. Censoring, shown in the fourth column, happens when a plan had not failed by the fourth quarter of 1995.

\footnotetext{
${ }^{8}$ Other sources were used in order to get data on some variables not available from the IFS and to fill some gaps in the data: annual data on real wages were obtained in the World Bank's World Tables; annual data on the debt service ratio were obtained from the World Debt Tables (also by the World Bank); and annual data on the unemployment rate were obtained from the Yearbook of National Account Statistics of the United Nations. Some gaps in the data were also filled with values obtained from computer data sources of the Instituto Brazileiro de Geografia e Estatística - IBGE (Brazilian quarterly real GDP growth since 1980 and the Brazilian quarterly unemployment rate since 1990) and INEGI-Mexico (Mexican quarterly real GDP growth since 1981 and the Mexican quarterly unemployment rate since 1987).

${ }^{9}$ For some countries only annual data is found on some variables, especially for earlier decades (1950s and 1960s). The variables for which interpolation was used to generate quarterly values are: real GDP; government deficit or surplus as a percentage of the GDP; current account as a percentage of GDP; real wages; unemployment rate; and debt service ratio.
} 


\section{-- Insert Table 2 about here --}

The hazard rate is defined as the conditional probability that failure occurs at time $t$ given that it has not already occurred. An estimate of the hazard rate can be obtained by dividing the number of plans that fail $\left(D_{t}\right)$ by the number at risk $\left(R_{t}\right)$. These empirical hazard rates are presented in the final column of Table 2, and Figure 6 shows graphically the evolution of the hazard rate.

\section{-- Insert Figure 6 about here --}

In the present case, I want to consider how the probability of failure of stabilizations depends on a set of macroeconomic variables. In order to do so, I created a separate observation for each quarter in which each plan was observed from implementation until failure, or censoring. This means that each plan contributed a number of observations equal to its duration in quarters. For each quarter and each plan the dependent variable (FAIL) takes the value of one if the stabilization plan failed in that quarter, and zero if it failed after that quarter. If it never fails, $F A I L$ takes the value of zero for all observations of that plan.

\subsection{Probit model}

In order to identify the variables that increase or decrease the probability of failure of a stabilization plan a binary probit model was estimated, linking the dependent variable to a set of 
explanatory variables reflecting the evolution of the economy. Here I assume that the unobserved hazard rate depends only on the following explanatory variables:

- accumulated real exchange rate appreciation ${ }^{10}$ : although it is endogenous in the model of the last section, the real exchange rate is a component of the adjustment effort in the models of Dornbusch (1991) and Orphanides (1996). Real appreciation is expected to increase the probability of failure of a stabilization;

- government deficit or surplus as a percentage of GDP: choice variable in the three models referred to above, that is expected to be negatively related to plan failure;

- quarterly growth in total reserves minus gold: the behavior of reserves is endogenous in the B.O.P. crises model, but partly exogenous in Dornbusch (1991) and Orphanides (1996), given the stochastic component of the demand for reserves they assume. An increase in reserves is expected to decrease the probability of failure;

- total reserves as a percentage of imports: proxy for the stock of reserves. The comments on the last variable also apply for the stock of reserves.

Other variables not so directly related to the models presented but that can influence the outcome of a stabilization were used as controls:

\footnotetext{
10 This variable is an index that starts at 100 in the first quarter of implementation and that reflects the
} accumulated real appreciation of the national currency since the beginning of the plan. 
- growth since same quarter of the previous year of real GDP: faster economic growth is expected to decrease the probability of failure of a stabilization;

- current account as a percentage of GDP: a larger positive balance is expected to decrease the probability of failure;

- country dummies: a dummy variable was created for each of the nine countries. Then, eight are included in the model in order to control for fixed effects.

The estimated model is the following:

$P\left(F A I L_{i, t}=1 \mid F A I L_{i, s}=1\right.$ for some $\left.s \geq t\right)=\lambda \cdot I(L)_{i, t}+\varepsilon_{i, t}$

where $I(L)_{i t}$ is a set of contemporaneous and/or lagged independent variables (for plan $i$ at time $t$ ), and $\lambda$ is the vector of respective coefficients.

Results of probit estimations are reported on Table 3. The contemporaneous values of the explanatory variables are used in the first estimation. Since the failure of a plan in one quarter will probably influence the values of the explanatory variables in that quarter and in the following ones, the failure of a plan may be more appropriately modeled as a function of the lags than by the contemporaneous values. To consider the importance of this possibility, I also estimate several models using various lag structures for the independent variables. One option is to lag all variables 
one period, which I do, but it is also possible that there are lagged effects of more than one quarter. Unfortunately, as there are only 28 positive observations (when $F A I L=1$ ), one cannot use many lags at the same time. That problem was avoided by modeling the lags as moving averages of the contemporaneous variables and 1,2,3, or 4 lags, keeping the number of degrees of freedom constant. ${ }^{11}$

\section{-- Insert Table 3 about here}

Since probit coefficients are not very intuitive, estimates of the derivative of the probability with respect to the independent variables (converted to percentages), are also reported. These give the effects of one-unit (percentage point) changes in the regressors on the probability of failure (also expressed in percentage points), evaluated at the mean of the data. T-statistics for the null of no effect and the associated p-values are also reported.

The statistical evidence of an effect is strongest for the accumulated real exchange rate appreciation and the government budget as a percentage of GDP. These results do not change significantly across the first four specifications using various lag structures. The signs of the estimated coefficients are also as predicted by the theory: real appreciation increases the

\footnotetext{
${ }^{11}$ In the first estimation, the first lag of real exchange rate appreciation was used instead of the contemporaneous value because there is usually a big devaluation of the national currency in the quarter of failure, improving the real exchange rate, which means that the first lag reflects better the accumulated real appreciation until failure. The change in total reserves is not lagged on the second estimation because the major losses of foreign reserves that generally precede the failure of an ERBS come in the quarter of failure and not before. The contemporaneous value of the real exchange rate appreciation is not included in the moving averages for the same reason that it is not included in the regression with contemporaneous values. Only the results of the first two estimations performed with moving averages are reported in Table 3 .
} 
probability of failure, and a government budget surplus decreases it. Total reserves as a percentage of imports is also usually significant and with the expected sign. The quarterly growth of total reserves is usually not significant, with the only exception being the model with the first lags of the variables (second column). This may indicate that the stock of reserves is more important for explaining the failure of stabilizations than the quarterly change in total reserves (the change in the stock). For the control variables, the current account as a percentage of GDP is always significant and with the expected sign. Real GDP growth is also significant, and with the expected sign, but only when its first lag or moving averages are used. Although the results are not presented, there is also statistical evidence in favor of the presence of country fixed effects.

The estimated slope derivatives are relatively small, but that does not mean that the effect of the regressors is negligible. A one percentage point increase in the accumulated real appreciation would only increase the probability of failure by 0.2 percentage points (see first column), but an increase of 50 percentage points would increase it by roughly 10 percentage points, which is by no means negligible (nor unusual). The slope derivative is higher for the government deficit or surplus as a percentage of GDP (1.51) but since this variable does not fluctuate as much as real appreciation, it is difficult to say which of them leads to higher effects on the probability of failure of stabilizations.

Finally, possible interaction effects between the independent variables are tested by adding one interaction term to the initial set of regressors and working only with continuous variables. One interaction I considered was between the first lag of real exchange rate appreciation and total reserves as a percentage of imports $[R E R(-1) *(T R / I M P)]$. This variable is statistically significant 
(see the 5th column), which means that the effect of real exchange rate appreciation on the probability of failure of a stabilization is influenced by the stock of reserves, and vice-versa. Interaction terms were created for all the four possible combinations of these two variables and government deficit or surplus as a percentage of GDP. Of the four estimations only the one reported in the fifth column of Table 3 showed some evidence of interactive effects.

Although my purpose is to show that the same results hold for a wide set of specifications, one could use the Schwartz Bayesian Information Criterion to determine which is the best model specification. ${ }^{12}$ After comparing the specifications referred to above and trying some other alternatives, the one that was found to maximize the SBIC is the one reported in the last column of Table 3. The conclusions made before concerning the most statistically significant variables still hold, and it seems that one can do well with a more parsimonious model that does not include the change in total reserves and real GDP growth.

I also performed a considerable number of robustness tests not reported here: using periodaverage instead of end-of-period exchange rates in the computation of the real exchange rate; adding growth in private credit, domestic credit, or money to the list of regressors (one at a time); adding exports and imports, the debt service ratio, interest rates, the unemployment rate, and growth in real wages to the list of regressors, either jointly or one at a time. None of these changed results significantly. 
The possibility of threshold and interactive effects concerning the three most statistically significant variables was also accounted for including threshold and interactive dummies in the set of regressors. Several reference amounts for these dummies were tried but results, not reported here, do not show evidence of threshold or interactive effects.

Sensitivity analysis was performed estimating all the previous specifications for two alternative samples. First, for a sample that included only ERBS, so that possible different effects of the variables on money-based plans would be excluded. Results, not reported here, were virtually identical to those of Table 3. Second, for a sample containing only major stabilization plans, that is, the ones that were able to reduce inflation considerably, lasted for some time, and are more frequently referred to in the literature. ${ }^{13}$ Results of the first three estimations for this second sample are reported in Table 4, and they show, again, the most statistical evidence for accumulated real appreciation, government deficit or surplus as a percentage of GDP, and total reserves as a percentage of imports.

\section{-- Insert Table 4 about here --}

\footnotetext{
12 This criterion incorporates the basic concerns of model selection: precision of the estimate (represented by the $\log$ of the likelihood function), and parsimony in the parametrization (penalizes larger parametrizations). According to Geweke and Meese (1981), this criterion leads to asymptotically efficient estimates of the parameters in the true model. The model that maximizes the SBIC is supposed to be one that best represents reality. On the SBIC and other information criteria see: Judge et al. (1985), and Schwartz (1978).

${ }^{13}$ The stabilization plans excluded were (see Table 1): the first four in Bolivia; Bresser and Summer plans in Brazil; the first four in Israel; the first in the Dominican Republic; and the second in Peru (1988.1-1988.3).
} 


\subsection{Probit model with the hazard rate changing autonomously over time}

The previous model assumed that the baseline hazard rate of a plan did not change autonomously over time, meaning that any variation had to be due to changes in the explanatory variables. One simple way to relax the constraint imposed, allowing the hazard rate to change over time even when other variables are held constant, is to create a set of dummy variables accounting for the passage of time and add them to the list of regressors of the probit estimation. ${ }^{14}$

Year dummies were included in the set of regressors. ${ }^{15}$ Results did not change significantly (see last three columns of Table 4), none of the dummies was individually significant, and one is never able to reject the null hypothesis that the coefficients on the year dummies were all equal to zero at normal levels of significance. These results show that it does not make much difference whether dummy variables accounting for the passage of time are included or not in the set of regressors of the probit model. ${ }^{16}$

\footnotetext{
${ }^{14}$ See Allison (1982) for an example with a Logit model. He also compares the results of two Logit models with one assuming that the hazard rate does not change autonomously over time, and the other relaxing that constraint by adding year dummies to the list of regressors.

${ }^{15}$ Seven dummies were created, each related to a certain year in the life of a plan: one for each of the first six years of implementation and a $7^{\text {th }}$ for all the remaining years (no stabilization failed after 7 years).

${ }^{16}$ The regressions of Table 3 and Table 4 were also estimated with a Proportional Hazards model following the discrete-time specification of the hazard rate developed by Prentice and Gloeckler (1978). Results, not reported here, show little difference from those of the probit model.
} 


\section{POLITICAL FACTORS BEHIND BUDGET DEFICITS}

Results above clearly show that budget deficits are one of the main causes of failure of inflation stabilization programs. Since politicians are very likely to be aware of this fact, we may ask why some governments allow budget deficits to persist or take so long to eliminate them. According to Edwards and Tabellini (1991), Roubini (1991), and Cukierman, Edwards, and Tabellini (1992), models based on the optimal taxation theory do not provide an answer to this question. Instead, political factors such as political instability and polarization should be taken into account.

They suggest that the smaller the probability of the current government being reelected and the greater the degree of ideological polarization of the political system, the more inefficient will be the tax system left for future governments and the more will be borrowed in excess of the optimum. The resulting debt would have to be paid by the next government, and an inefficient tax system would act as a constraint on its spending ability in programs the incumbent government may not like. The authors show that variables related to political instability have a significant positive relationship with inflation, seigniorage, budget deficits, and public debt across the countries in their samples.

Alesina and Drazen (1991) present a model in which delays of fiscal stabilization result from the failure of rival interest groups to agree on a deficit reduction program. This "war of attrition" persists until the two groups agree on how the burden of higher taxation is going to be distributed across them. Ideological polarization, political fragmentation, lower costs of inflation, and greater dispersion of income across interest groups can delay fiscal stabilization. Drazen and Grilli (1993) 
extend this model emphasizing the possible benefits of economic crises. Since higher costs of delay hasten stabilizations, a crisis may be welfare improving if its welfare costs are more than compensated for by the benefits of earlier stabilization. Fernandez and Rodrik (1991) present a model in which a reform that benefits the country as a whole can be rejected by a majority of the population when the identity of the losers cannot be determined ex ante.

These models imply that "Actions that are optimal in a purely economic sense may not be optimal at all once political influence enters the picture." (Lothian, 1991, p. S6). That is, it may be optimal to delay a stabilization program when political instability, ideological polarization, and payoff uncertainty are taken into consideration. They also suggest that what matters most for the success or failure of a stabilization is the political will to reduce deficits and to keep them low. Thus, one possible extension of the empirical work of the present paper is to include variables related to political instability, polarization, and payoff uncertainty in the set of explanatory variables.

Political factors may also help explain why lags of stabilizations were larger in chronic inflation experiences than in the hyperinflations of the 1920s. As the latter were war related, agents expected deficits to be reduced after the war. Since economic agents probably realized that the same was not true for chronic inflation countries, high inflation took longer to be eliminated there. ${ }^{17}$ The models of Alesina and Drazen (1991) and Drazen and Grilli (1993) may also help explain why the lags in adjustments have been larger in chronic inflation countries. Since inflation was much higher during hyperinflations, the costs of delaying stabilization were also much higher,

\footnotetext{
${ }^{17}$ I owe this rationale to an anonymous referee.
} 
providing a greater incentive for the contending interest groups to agree on a stabilization program. Indexation schemes introduced in some chronic inflation countries also reduced the costs of living under high inflation and the urgency to stabilize, leading to longer delays.

\section{CONCLUSIONS}

A binary probit model was used over a panel of 34 stabilization programs, implemented in nine different countries, in order to identify the macroeconomic variables that have more effect on the probability of failure of a stabilization program. Empirical results are consistent with my model of plan failure, with the stylized facts of inflation stabilization, and with credibility models found in the literature. Accumulated real exchange rate appreciation, total foreign reserves as a percentage of imports, and government deficit or surplus as a percentage of GDP, commonly connected to the failure of stabilizations, are highly statistically significant across different specifications and samples. Furthermore, their effect on the probability of failure of a stabilization is in accordance with the theory, and the magnitude of their influence is considerable.

The main conclusions that can be extracted from these results are that the fiscal situation must be taken care of if the plan is expected to succeed, and that real appreciation may turn itself into a serious problem. The small coefficients associated with total reserves as a percentage of imports imply that the stock of reserves may not be as important as the other two variables, or as the model of Orphanides (1996) could imply (basing the decision of starting or abandoning a stabilization on the available stock of reserves). As shown in my model, if budget deficits financed by money creation persist, reserves will be eroded sooner or later, regardless of the initial stock of 
reserves. Therefore, one of the top priorities for a government implementing an inflation stabilization program should be to stabilize the fiscal accounts, so that money creation though the government deficit is reduced. If an exchange rate based stabilization is adopted real appreciation of the national currency must be kept under control, so that external accounts and the stock of reserves do not reach dangerous levels, and the credibility of the fixed parity is not greatly reduced.

After identifying the main causes of failure of stabilizations, it may also be important to find out what underlies them. That is, one could also try to find out why budget deficits are not reduced earlier or why inflation is not reduced faster in order to avoid problems of real appreciation. As suggested in recent political economic literature, persistence of budget deficits and lags in stabilizations may be better explained by political factors than by optimizing models of taxation. In this literature, delays in stabilizations generally result from political instability, ideological polarization, or payoff uncertainty. Thus, one possible extension of the present paper would be to include variables related to those factors in the set of explanatory variables. 


\section{Acknowledgments}

The author wishes to thank John McDermott, McKinley Blackburn, Janice Breuer, Henry Chappell, and George Krause for very helpful comments. Financial support provided by Programa PRAXIS XXI - Portugal (Reference BD/3525/94).

\section{REFERENCES}

Agénor, P.R., 1994. Credibility and Exchange Rate Management in Developing Countries. Journal of Development Economics 45, 1-16.

Agénor, P.R., Flood, R.P., 1994. Macroeconomic Policy, Speculative Attacks, and Balance of Payments Crises. In van der Ploeg, F. (Ed.), The Handbook of International Macroeconomics. Blackwell Publishers, Cambridge, MA, pp. 224-250.

Alesina, A., Drazen, A., 1991. Why are Stabilizations Delayed? American Economic Review 81(5), 1170-1188.

Allison, P.D., 1982. Discrete-Time Methods for the Analysis of Event Histories. In Leinhardt, S. (Ed.), Sociological Methodology. Jossey-Bass Publishers, San Francisco, CA, pp. 6197.

Bruno, M., et al. (Eds.), 1988. Inflation Stabilization: The Experience of Israel, Argentina, Brazil, Bolivia, and Mexico. MIT Press, Cambridge, MA.

Bruno, M., et al., (Eds.), 1991. Lessons of Economic Stabilization and its Aftermath. MIT Press, Cambridge, MA.

Calvo, G.A., 1986. Temporary Stabilization: Predetermined Exchange Rates. Journal of Political Economy 94(6), 1319-1329. 
Calvo, G.A., 1991. Temporary Stabilization Policy: The Case of Flexible Prices and Exchange Rates. Journal of Economic Dynamics and Control 15, 197-213.

Calvo, G.A., Végh, C.A., 1994. Inflation Stabilization and Nominal Anchors. Contemporary Economic Policy XII, 35-45.

Connolly, M.B., Taylor, D., 1984. The Exact Timing of the Collapse of an Exchange Rate Regime and Its Impact on the Relative Price of Traded Goods. Journal of Money, Credit, and Banking 16(2), 194-207.

Cukierman, A., Edwards, S., Tabellini, G., 1992. Seignioriage and Political Instability. American Economic Review 82(3), 537-555.

Dornbush, R., 1991. Credibility and Stabilization. Quarterly Journal of Economics August, 837850.

Dornbush, R., Goldfajn, I., Valdés, R., 1995. Currency Crises and Collapses. Brookings Papers on Economic Activity 2:1995, 219-293.

Drazen, A., Grilli, V., 1993. The Benefit of Crises for Economic reforms. American Economic Review 83(3), 598-607.

Edwards, S., Tabellini, G., 1991. Explaining Fiscal Policy and Inflation in Developing Countries. Journal of International Money and Finance 10, S16-S48.

Fernandez, R., Rodrik, D., 1991. Resistance to Reform: Status Quo Bias in the Presence of Individual-Specific Uncertainty. American Economic Review 81(5), 1146-1155.

Flood, R.P., Garber, P.M., 1984. Collapsing Exchange Rate Regimes, Some Linear Examples. Journal of International Economics 17, 1-13.

Geweke, J., Meese, R., 1981. Estimating Regression Models of Finite but Unknown Order. International Economic Review 22(1), 55-70. 
Hoffmaister, A.W., Végh, C.A., 1996. Disinflation and the Recession-Now-Versus-RecessionLater Hypothesis: Evidence from Uruguay. IMF Staff Papers 43(2), 355-394.

Judge, G.G., et al., 1985. The Theory and practice of Econometrics, 2nd edition. John Wiley \& Sons, New York.

Lothian, J., 1991. Political factors in international economics: an overview. Journal of International Money and Finance 10, S4-S15.

Kiguel, M., Leviatan, N., 1991. The Inflation-Stabilization Cycles in Argentina and Brazil. In Bruno, M., et al. (Eds.), 1991. Lessons of Economic Stabilization and its Aftermath. MIT Press, Cambridge, MA, pp. 191-232.

Kiguel, M., Leviatan, N., 1992a., The Business Cycle Associated with Exchange Rate-Based Stabilizations. The World Bank Economic Review 6(2), 279-305.

Kiguel, M., Leviatan, N., 1992b., When do Heterodox Stabilization Programs Work?. The World Bank Research Observer 7(1), 35-57.

Krugman, P., 1979. A Model of Balance-of-Payments Crises. Journal of Money, Credit, and Banking 11(3), 311-325.

Obtsfeld, M., 1984. Balance-of-Payments Crises and Devaluation. Journal of Money, Credit, and Banking 16(2), 208-217.

Orphanides, A., 1996. The Timing of Stabilizations. Journal of Economic Dynamics and Control 20, 257-279.

Pazos, F., 1972. Chronic Inflation in Latin America. Praeger Publishers, New York.

Prentice, R., Gloeckler, L.A., 1978. Regression Analysis of Grouped Survival Data with Application to Breast Cancer Data. Biometrics 34 (March), 57-67. 
Rebelo, S., Végh, C.A., 1995. Real Effects of Exchange Rate-Based Stabilization: An Analysis of Competing Theories. NBER Macroeconomics Annual 1995, 126-187.

Roubini, N., 1991. Economic and Political Determinants of Budget Deficits in Developing Countries. Journal of International Money and Finance 10, S49-S72.

Sargent, T.J., 1982. The Ends of Four Big Inflations. In Hall, R. (Ed.), Inflation: Causes and Effects. The University of Chicago Press, Chicago, IL, pp. 41-97.

Schwartz, G., 1978. Estimating the Dimension of a Model. Annals of Statistics 6, 461-464.

United Nations, Yearbook of National Account Statistics. United Nations, NY, several issues.

Végh, C.A., 1992. Stopping High Inflation: An Analytical Overview. IMF Staff Papers 39(3), 626-695.

World Bank, World Debt Tables. World Bank, Washington, D.C., several issues.

World Bank, World Tables. John Hopkins University Press, Baltimore, MD, several issues. 
Table 1: Stabilization Programs

\begin{tabular}{|c|c|c|c|}
\hline Country & Program dates / names & Type & Duration \\
\hline Argentina & $\begin{array}{l}1959.3 \text { - } 1962.2 \\
1967.2 \text { - } 1970.2 \\
1973.3 \text { - } 1975.1 \\
1978.4 \text { - } 1981.1 \text { (Tablita) } \\
1985.1 \text { - } 1986.3 \text { (Austral) } \\
1990.1 \text { - } 1991.1 \text { (Bonex) } \\
1991.2 \text { - present (Convertibility) }\end{array}$ & $\begin{array}{l}\text { ERBS } \\
\text { ERBS } \\
\text { ERBS } \\
\text { ERBS } \\
\text { ERBS } \\
\text { MBS } \\
\text { ERBS }\end{array}$ & $\begin{array}{c}12 \\
13 \\
7 \\
10 \\
7 \\
5 \\
19+\end{array}$ \\
\hline Bolivia & $\begin{array}{l}1982.1-1982.4 \\
1983.1-1983.4 \\
1984.2-1984.3 \\
1985.1-1985.3 \\
1985.4-\text { present }\end{array}$ & $\begin{array}{l}\text { ERBS } \\
\text { ERBS } \\
\text { ERBS } \\
\text { ERBS } \\
\text { ERBS }\end{array}$ & $\begin{array}{c}4 \\
4 \\
2 \\
3 \\
41+\end{array}$ \\
\hline Brazil & $\begin{array}{l}1964: 2 \text { - 1968:3 } \\
1986: 1 \text { - 1986:4 (Cruzado) } \\
1987.2 \text { - 1988.1 (Bresser) } \\
\text { 1989.1 - 1989.3 (Summer) } \\
\text { 1990.2 - 1990.4 (Collor) } \\
1994.3 \text { - present (Real) }\end{array}$ & $\begin{array}{l}\text { ERBS } \\
\text { ERBS } \\
\text { ERBS } \\
\text { ERBS } \\
\text { MBS } \\
\text { ERBS }\end{array}$ & $\begin{array}{c}18 \\
4 \\
4 \\
3 \\
3 \\
6+\end{array}$ \\
\hline Chile & $\begin{array}{l}1975.2 \text { - } 1977.4 \\
1978.1 \text { - } 1982.2 \text { (Tablita) }\end{array}$ & $\begin{array}{l}\text { MBS } \\
\text { ERBS }\end{array}$ & $\begin{array}{l}11 \\
18\end{array}$ \\
\hline $\begin{array}{l}\text { Dominican } \\
\text { Republic }\end{array}$ & $\begin{array}{l}1988.3-1990.2 \\
1991.2 \text { - present }\end{array}$ & $\begin{array}{l}\text { ERBS } \\
\text { MBS }\end{array}$ & $\begin{array}{c}8 \\
19+\end{array}$ \\
\hline Israel & $\begin{array}{l}1980.4 \text { - } 1982.3 \text { (Aridor I) } \\
1982.3 \text { - 1983.3 (Aridor II) } \\
1983.4 \text { - 1984.3 (Cohen-Orgad) } \\
1984.4 \text { - 1985.2 (Pack. deal III) } \\
1985.3 \text { - present (Shekel) }\end{array}$ & $\begin{array}{l}\text { ERBS } \\
\text { ERBS } \\
\text { ERBS } \\
\text { ERBS } \\
\text { ERBS }\end{array}$ & $\begin{array}{c}8 \\
5 \\
4 \\
3 \\
42+\end{array}$ \\
\hline Mexico & $\begin{array}{l}1976.4-1982.1 \\
1988.1-1994.4\end{array}$ & $\begin{array}{l}\text { ERBS } \\
\text { ERBS }\end{array}$ & $\begin{array}{l}22 \\
28\end{array}$ \\
\hline Peru & $\begin{array}{l}1985.4-1987.4 \\
1988.1 \text { - } 1988.3 \\
1990.4 \text { - present }\end{array}$ & $\begin{array}{l}\text { ERBS } \\
\text { ERBS } \\
\text { MBS }\end{array}$ & $\begin{array}{c}9 \\
3 \\
21+\end{array}$ \\
\hline Uruguay & $\begin{array}{l}1968.2 \text { - } 1971.4 \\
1978.4-1982.4 \text { (Tablita) }\end{array}$ & $\begin{array}{l}\text { ERBS } \\
\text { ERBS }\end{array}$ & $\begin{array}{l}15 \\
17\end{array}$ \\
\hline
\end{tabular}

Sources: Bruno, et al. (1988); Bruno, et al. (1991); Calvo and Végh (1994); Kiguel and Leviatan (1991, 1992a); and Végh (1992). 
Table 2: Distribution of Quarter of Plan Failure

\begin{tabular}{|c|c|c|c|c|}
\hline $\begin{array}{c}\text { Quarter } \\
t\end{array}$ & $\begin{array}{c}\text { Risk set } \\
\mathrm{R}_{\mathrm{t}}\end{array}$ & $\begin{array}{c}\text { Failures } \\
D_{t}\end{array}$ & $\begin{array}{c}\text { Censorings } \\
\mathrm{C}_{\mathrm{t}}\end{array}$ & $\begin{array}{c}\text { Hazard } \\
\mathrm{H}_{\mathrm{t}}\end{array}$ \\
\hline 1 & 34 & 0 & 0 & 0.000 \\
\hline 2 & 34 & 1 & 0 & 0.029 \\
\hline 3 & 33 & 5 & 0 & 0.152 \\
\hline 4 & 28 & 5 & 0 & 0.179 \\
\hline 5 & 23 & 2 & 0 & 0.087 \\
\hline 6 & 21 & 0 & 1 & 0.000 \\
\hline 7 & 20 & 2 & 0 & 0.100 \\
\hline 8 & 18 & 2 & 0 & 0.111 \\
\hline 9 & 16 & 1 & 0 & 0.063 \\
\hline 10 & 15 & 1 & 0 & 0.067 \\
\hline 11 & 14 & 1 & 0 & 0.071 \\
\hline 12 & 13 & 1 & 0 & 0.077 \\
\hline 13 & 12 & 1 & 0 & 0.083 \\
\hline 14 & 11 & 0 & 0 & 0.000 \\
\hline 15 & 11 & 1 & 0 & 0.091 \\
\hline 16 & 10 & 0 & 0 & 0.000 \\
\hline 17 & 10 & 1 & 0 & 0.100 \\
\hline 18 & 9 & 2 & 0 & 0.222 \\
\hline 19 & 7 & 0 & 2 & 0.000 \\
\hline 20 & 5 & 0 & 0 & 0.000 \\
\hline 21 & 5 & 0 & 1 & 0.000 \\
\hline 22 & 4 & 1 & 0 & 0.250 \\
\hline 23 & 3 & 0 & 0 & 0.000 \\
\hline 24 & 3 & 0 & 0 & 0.000 \\
\hline 25 & 3 & 0 & 0 & 0.000 \\
\hline 26 & 3 & 0 & 0 & 0.000 \\
\hline 27 & 3 & 0 & 0 & 0.000 \\
\hline 28 & 3 & 1 & 0 & 0.333 \\
\hline 29 & 2 & 0 & 0 & 0.000 \\
\hline 30 & 2 & 0 & 0 & 0.000 \\
\hline 31 & 2 & 0 & 0 & 0.000 \\
\hline 32 & 2 & 0 & 0 & 0.000 \\
\hline 33 & 2 & 0 & 0 & 0.000 \\
\hline 34 & 2 & 0 & 0 & 0.000 \\
\hline 35 & 2 & 0 & 0 & 0.000 \\
\hline 36 & 2 & 0 & 0 & 0.000 \\
\hline 37 & 2 & 0 & 0 & 0.000 \\
\hline 38 & 2 & 0 & 0 & 0.000 \\
\hline 39 & 2 & 0 & 0 & 0.000 \\
\hline 40 & 2 & 0 & 0 & 0.000 \\
\hline 41 & 2 & 0 & 1 & 0.000 \\
\hline 42 & 1 & 0 & 1 & 0.000 \\
\hline Total & 398 & 28 & 6 & \\
\hline
\end{tabular}

Source: Table 1.

Notes: $\mathrm{R}_{\mathrm{t}}=\mathrm{R}_{\mathrm{t}-1}-\mathrm{D}_{\mathrm{t}-1}-\mathrm{C}_{\mathrm{t}-1} ; \mathrm{H}_{\mathrm{t}}=\mathrm{D}_{\mathrm{t}} / \mathrm{R}_{\mathrm{t}}$ 
Table 3: Probit Results

\begin{tabular}{|c|c|c|c|c|c|c|}
\hline & $\begin{array}{l}\text { Comtem- } \\
\text { poraneous }\end{array}$ & First lags & $\begin{array}{c}\text { MA of } \\
\text { contemp }+ \\
1 \text { lag }\end{array}$ & $\begin{array}{c}\text { MA of } \\
\text { contemp }+ \\
2 \text { lags }\end{array}$ & $\begin{array}{l}\text { Comtem- } \\
\text { poraneous }\end{array}$ & $\begin{array}{l}\text { Comtem- } \\
\text { poraneous }\end{array}$ \\
\hline $\begin{array}{l}\text { Real Exchange Rate } \\
\text { Appreciation (1st lag) }\end{array}$ & $\begin{array}{c}.023576 \\
(4.16)^{* * *} \\
{[.199]}\end{array}$ & $\begin{array}{c}.024754 \\
(4.54) * * * \\
{[.206]}\end{array}$ & $\begin{array}{c}.024094 \\
(4.40) * * * \\
{[.203]}\end{array}$ & $\begin{array}{c}.032422 \\
(4.64)^{* * *} \\
{[.272]}\end{array}$ & $\begin{array}{c}.049455 \\
(3.45)^{* * *} \\
{[.399]}\end{array}$ & $\begin{array}{c}.024420 \\
(4.49)^{* * * *} \\
{[.209]}\end{array}$ \\
\hline $\begin{array}{l}\text { Government Surplus as } \\
\text { percentage of GDP }\end{array}$ & $\begin{array}{c}-.179710 \\
(-5.02)^{* * *} \\
{[-1.51]}\end{array}$ & $\begin{array}{c}-.173916 \\
(-4.88) * * * \\
{[-1.45]}\end{array}$ & $\begin{array}{c}-.178032 \\
(-4.82)^{* * *} \\
{[-1.50]}\end{array}$ & $\begin{array}{c}-.193602 \\
(-4.98) * * * \\
{[-1.62]}\end{array}$ & $\begin{array}{c}-.186104 \\
(-5.01)^{* * *} \\
{[-1.50]}\end{array}$ & $\begin{array}{c}-.192533 \\
(-5.48) * * * \\
{[-1.65]}\end{array}$ \\
\hline $\begin{array}{l}\text { Total Reserves } \\
\text { (quarterly growth) }\end{array}$ & $\begin{array}{c}-.004705 \\
(-1.02) \\
{[-.039]}\end{array}$ & $\begin{array}{c}-.010365 \\
(-2.11)^{* *} \\
{[-.086]}\end{array}$ & $\begin{array}{c}-.008439 \\
(-1.35) \\
{[-.071]}\end{array}$ & $\begin{array}{c}-.004863 \\
(-.78) \\
{[-.040]}\end{array}$ & $\begin{array}{c}-.004549 \\
(-.93) \\
{[-.036]}\end{array}$ & \\
\hline $\begin{array}{l}\text { Total Reserves as a } \\
\text { Percentage of Imports }\end{array}$ & $\begin{array}{c}-.005816 \\
(-2.59) * * * \\
{[-.049]}\end{array}$ & $\begin{array}{c}-.004674 \\
(-2.38)^{* *} \\
{[-.039]}\end{array}$ & $\begin{array}{c}-.005114 \\
(-2.40)^{* *} \\
{[-.043]}\end{array}$ & $\begin{array}{c}-.005258 \\
(-2.37)^{* *} \\
{[-.044]}\end{array}$ & $\begin{array}{c}-.014115 \\
(1.50) \\
{[-.113]}\end{array}$ & $\begin{array}{c}-.006103 \\
(-2.79) * * * \\
{[-.052]}\end{array}$ \\
\hline $\begin{array}{l}\text { Real GDP } \\
\text { (4 quarter growth) }\end{array}$ & $\begin{array}{c}-.035374 \\
(-1.39) \\
{[-.298]}\end{array}$ & $\begin{array}{c}-.054279 \\
(-1.97)^{* *} \\
{[-.453]}\end{array}$ & $\begin{array}{c}-.050150 \\
(-1.73)^{*} \\
{[-.424]}\end{array}$ & $\begin{array}{c}-.057412 \\
(-1.79)^{*} \\
{[-.483]}\end{array}$ & $\begin{array}{c}-.072396 \\
(-2.39) * * \\
{[-.584]}\end{array}$ & \\
\hline $\begin{array}{l}\text { Current Account as } \\
\text { percentage of GDP }\end{array}$ & $\begin{array}{c}-.154065 \\
(-2.63)^{* * *} \\
{[-1.30]}\end{array}$ & $\begin{array}{c}-.176876 \\
(-3.00) * * * \\
{[-1.47]}\end{array}$ & $\begin{array}{c}-.164890 \\
(-2.73)^{* * *} \\
{[-1.39]}\end{array}$ & $\begin{array}{c}-.201473 \\
(-3.09) * * \\
{[-1.69]}\end{array}$ & $\begin{array}{c}-.158491 \\
(-2.69) * * * \\
{[-1.27]}\end{array}$ & $\begin{array}{c}-.171797 \\
(-2.99) * * * \\
{[-1.47]}\end{array}$ \\
\hline $\begin{array}{l}\text { Interaction term } \\
\operatorname{RER}(-1)^{*}(\mathrm{TR} / \mathrm{IMP})\end{array}$ & & & & & $\begin{array}{c}-.000160 \\
(-2.06)^{* *} \\
{[-.001]}\end{array}$ & \\
\hline $\begin{array}{l}\text { Log of Likelihood } \\
\text { Function }\end{array}$ & -60.65 & -60.79 & -60.78 & -60.74 & -57.22 & -62.23 \\
\hline $\begin{array}{l}\text { Likelihood Ratio } \\
\text { (Joint test for coeff. } \chi^{2} \text { ) }\end{array}$ & $81.1 * * *$ & $80.8 * * *$ & $80.9 * * *$ & $80.9 * * *$ & $88 * * *$ & $78 * * *$ \\
\hline $\begin{array}{l}\text { Likelihood Ratio Index } \\
\text { (McFadden's } \mathrm{R}^{2} \text { ) }\end{array}$ & .40 & .3995 & .3996 & .40 & .4347 & .3853 \\
\hline $\begin{array}{l}\text { Schwartz Bayesian } \\
\text { Information Criterion }\end{array}$ & -102.28 & -102.51 & -102.41 & -102.37 & -101.83 & -97.91 \\
\hline
\end{tabular}

Sources: IMF - IFS, IBGE, and, INEGI.

Notes: - the column titles indicate the lag structure used.

- the first lag of real GDP growth is used on the 5th estimation.

- t-statistics are in parenthesis.

- The number of stars reveals the significance level at which the relevant null hypothesis is rejected: *** for $1 \%$,** for $5 \%$, and $*$ for $10 \%$.

- Probit slope derivatives converted to percentages $((\mathrm{dP} / \mathrm{dX}) * 100)$ are in brackets.

- Model estimated with a constant and eight country dummies, by Maximum Likelihood. 
Table 4: Sensitivity Analysis and Probit with Year Dummies

\begin{tabular}{|c|c|c|c|c|c|c|}
\hline & \multicolumn{3}{|c|}{ “Major” stabilizations only } & \multicolumn{3}{|c|}{ Probit with year dummies } \\
\hline & $\begin{array}{l}\text { Comtem- } \\
\text { poraneous }\end{array}$ & First lags & $\begin{array}{c}\text { MA of } \\
\text { contemp }+ \\
1 \text { lag }\end{array}$ & $\begin{array}{l}\text { Comtem- } \\
\text { poraneous }\end{array}$ & First lags & $\begin{array}{c}\text { MA of } \\
\text { contemp }+ \\
1 \text { lag }\end{array}$ \\
\hline $\begin{array}{l}\text { Real Exchange Rate } \\
\text { Appreciation (1st lag) }\end{array}$ & $\begin{array}{c}.035031 \\
(3.91)^{* * *} \\
{[.187]}\end{array}$ & $\begin{array}{c}.034052 \\
(3.97) * * * \\
{[.189]}\end{array}$ & $\begin{array}{c}.033678 \\
(3.75)^{* * *} \\
{[.183]}\end{array}$ & $\begin{array}{c}.025082 \\
(3.66) * * * \\
{[.206]}\end{array}$ & $\begin{array}{c}.024743 \\
(4.05) * * * \\
{[.201]}\end{array}$ & $\begin{array}{c}.024485 \\
(3.94) * * * \\
{[.202]}\end{array}$ \\
\hline $\begin{array}{l}\text { Government Surplus as } \\
\text { percentage of GDP }\end{array}$ & $\begin{array}{c}-.232332 \\
(-3.61)^{* * *} \\
{[-1.24]}\end{array}$ & $\begin{array}{c}-.198715 \\
(-3.26)^{* * *} \\
{[-1.10]}\end{array}$ & $\begin{array}{c}-.214988 \\
(-3.32) * * * \\
{[-1.17]}\end{array}$ & $\begin{array}{c}-.197011 \\
(-4.65)^{* * *} \\
{[-1.62]}\end{array}$ & $\begin{array}{c}-.200271 \\
(-4.61)^{* * *} \\
{[-1.62]}\end{array}$ & $\begin{array}{c}-.197783 \\
(-4.49) * * * \\
{[-1.63]}\end{array}$ \\
\hline $\begin{array}{l}\text { Total Reserves } \\
\text { (quarterly growth) }\end{array}$ & $\begin{array}{c}-.002010 \\
(-.44) \\
{[-.010]}\end{array}$ & $\begin{array}{c}-.007771 \\
(-1.46) \\
{[-.043]}\end{array}$ & $\begin{array}{l}-.008236 \\
(-1.12) \\
{[-.044]}\end{array}$ & $\begin{array}{c}-.005700 \\
(-1.09) \\
{[-.046]}\end{array}$ & $\begin{array}{c}-.011453 \\
(-2.12)^{* *} \\
{[-.093]}\end{array}$ & $\begin{array}{c}-.009207 \\
(-1.33) \\
{[-.076]}\end{array}$ \\
\hline $\begin{array}{l}\text { Total Reserves as a } \\
\text { Percentage of Imports }\end{array}$ & $\begin{array}{c}-.006246 \\
(-2.59) * * * \\
{[-.033]}\end{array}$ & $\begin{array}{c}-.005776 \\
(-2.59) * * * \\
{[-.032]}\end{array}$ & $\begin{array}{c}-.005869 \\
(-2.47)^{* * *} \\
{[-.032]}\end{array}$ & $\begin{array}{c}-.006962 \\
(-2.72)^{* * *} \\
{[-.057]}\end{array}$ & $\begin{array}{c}-.005109 \\
(-2.39) * * \\
{[-.041]}\end{array}$ & $\begin{array}{c}-.005973 \\
(-2.54) * * \\
{[-.049]}\end{array}$ \\
\hline $\begin{array}{l}\text { Real GDP } \\
\text { (4 quarter growth) }\end{array}$ & $\begin{array}{c}-.032637 \\
(-1.11) \\
{[-.174]}\end{array}$ & $\begin{array}{c}-.044380 \\
(-1.43) \\
{[-.247]}\end{array}$ & $\begin{array}{c}-.043896 \\
(-1.33) \\
{[-.239]}\end{array}$ & $\begin{array}{c}-.034362 \\
(-1.20) \\
{[-.282]}\end{array}$ & $\begin{array}{c}-.058525 \\
(-1.82)^{*} \\
{[-.476]}\end{array}$ & $\begin{array}{c}-.050984 \\
(-1.57) \\
{[-.421]}\end{array}$ \\
\hline $\begin{array}{l}\text { Current Account as } \\
\text { percentage of GDP }\end{array}$ & $\begin{array}{c}-.134801 \\
(-1.91)^{*} \\
{[-.719]}\end{array}$ & $\begin{array}{c}-.126879 \\
(-1.88)^{*} \\
{[-.706]}\end{array}$ & $\begin{array}{c}-.125931 \\
(-1.77)^{*} \\
{[-.687]}\end{array}$ & $\begin{array}{c}-.146229 \\
(-2.46) * * \\
{[-1.20]}\end{array}$ & $\begin{array}{c}-.167132 \\
(-2.81)^{* * *} \\
{[-1.35]}\end{array}$ & $\begin{array}{c}-.155425 \\
(-2.57) * * \\
{[-1.28]}\end{array}$ \\
\hline $\begin{array}{l}\text { Log of Likelihood } \\
\text { Function }\end{array}$ & -33.79 & -35.93 & -30.36 & -58.38 & -58.91 & -58.93 \\
\hline $\begin{array}{l}\text { Likelihood Ratio } \\
\text { (Joint test for coeff. } \chi^{2} \text { ) }\end{array}$ & $62.1 * * *$ & $57.8 * * *$ & $68.9 * * *$ & $85.7 * * *$ & $84.6 * * *$ & $84.6 * * *$ \\
\hline $\begin{array}{l}\text { Likelihood Ratio Index } \\
\text { (McFadden's } \mathrm{R}^{2} \text { ) }\end{array}$ & .4789 & .4459 & .5318 & .4233 & .4180 & .4179 \\
\hline $\begin{array}{l}\text { Schwartz Bayesian } \\
\text { Information Criterion }\end{array}$ & -74.44 & -76.69 & -71.01 & -120.83 & -121.50 & -121.38 \\
\hline
\end{tabular}

Sources: IMF - IFS, IBGE, and INEGI.

Notes: - the column titles indicate the lag structure used.

- $\mathrm{t}$-statistics are in parenthesis.

- The number of stars reveals the significance level at which the relevant null hypothesis is rejected: $* * *$ for $1 \%, * *$ for $5 \%$, and $*$ for $10 \%$.

- Probit slope derivatives converted to percentages $((\mathrm{dP} / \mathrm{dX}) * 100)$ are in brackets.

- Model estimated with a constant and eight country dummies, by Maximum Likelihood. 


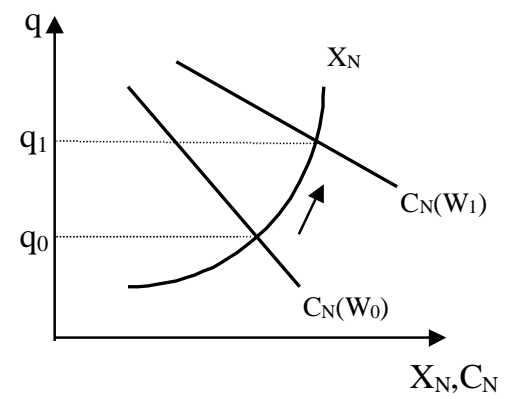

Figure 1: Non-traded Goods 


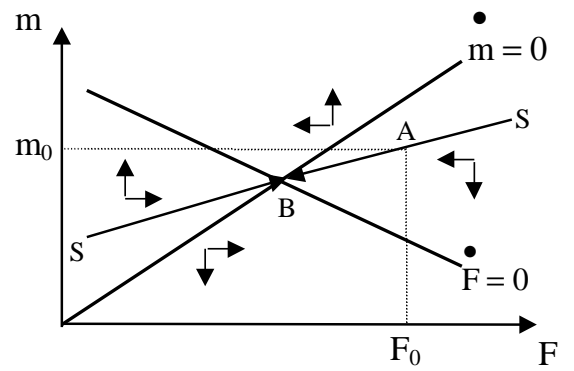

Figure 2: Flexible Exchange Rates 


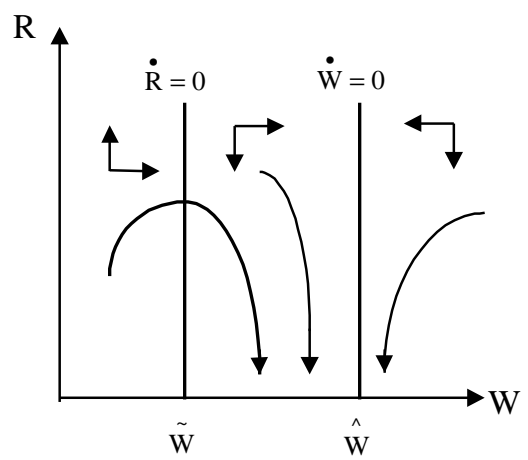

Figure 3: Fixed Exchange Rates 


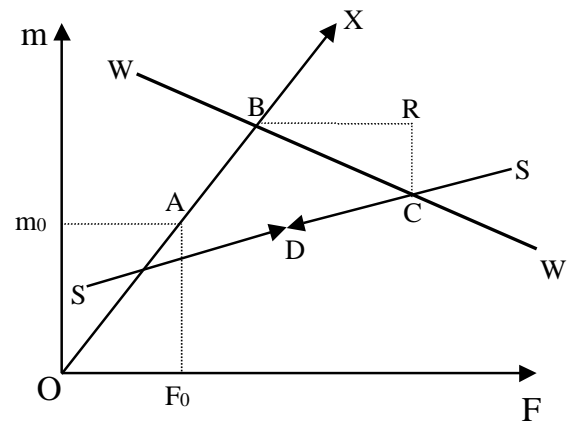

Figure 4: Speculative Attack 


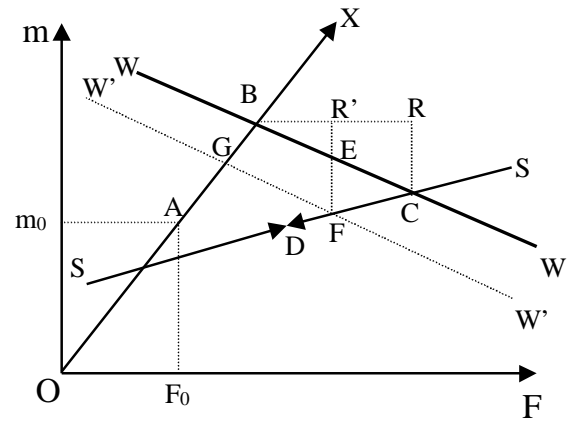

Figure 5: Speculative Attack and Devaluation 


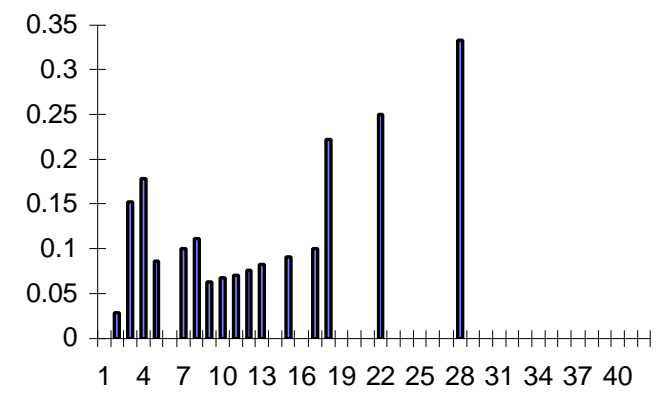

Figure 6: Hazard Rate 